DOI 10.37882/2223-2982.2020.05-2.20

\title{
ЖИВОТНОВОДСТВО В ХОЗЯЙСТВЕННОЙ ДЕЯТЕЛЬНОСТИ И ЖИЗНЕОБЕСПЕЧЕНИИ КАЗАХОВ ЧУЙСКОЙ СТЕПИ РЕСПУБЛИКИ АЛТАЙ
}

\section{STOCK-BREEDING IN THE ECONOMIC ACTIVITY AND THE LIFE SUPPORT OF THE KAZAKHS OF THE CHUI STEPPE IN THE ALTAI REPUBLIC}

\section{E. Torushev}

Summary: Stock-breeding activity of the Kazakh's population of the Chui steppe in the Altai Republic is examined in this article. Naturalclimatic conditions of the region are discussed which are determined the formation of the system of pasture-based stock-breeding. The methods of keeping domestic animals are investigated in the study region. It is discussed the question of the role of livestock products in life support of the Kazakhs of the Chui steppe.

Keywords: Kazakh's population, the distant-pasture animal stockbreeding, meat and dairy products, the Chui steppe, the Altai Republic.
Ж ивотноводство всегда составляло основу хозяйственной деятельности населения Горного Алтая. В современности в Республике Алтай одним из скотоводческих районов является Кош-Агачсий, где вместе с коренным населением алтайцами-теленгитами живут казахи.

Цель данной работы исследовать элементы животноводческой деятельности в системе жизнеобеспечения локальной группы казахов Чуйской степи Кош-Агачского района Республики Алтай. В статье будут рассмотрены казахское население трех сел: Кош-Агач, Тобелер и Жана-Аул, так как в этих населенных пунктах проживают основная часть изучаемой этнической группы в Чуйской степи. Хронологические рамки работы охватывают 1990 - 2010-е гг. В указанное время животноводство, как и в предшествующие периоды, продолжает играть важную роль в жизнеобеспечении казахов Кош-Агачского района Республики Алтай.

Приграничную область Юга-Востока Алтая (территория современного Кош-Агачского района) этническая группа казахов начала осваивать в последней трети XIX В. В конце XIX в. на исследуемой территории казахи кочевали на тех же местах, что и алтайцы-теленгиты. Однако некоторое обособление землепользования существовало. Левый берег р. Чуи от ее притока Чаган-Бургазы вниз по течению оставался местом кочевий теленгитов, а

\author{
Торушев Эркем Геннадьевич \\ К.и.н., с.н.С., БНУ РА «Научно-исследовательский \\ институт алтаистики им. С.С. Суразакова» \\ (2. Горно-Алтайск) \\ erktor@mail.ru
}

Аннотация: В статье исследуется животноводческая деятельность казахского населения Чуйской степи Республики Алтай. Рассмотрены природно-климатические условия региона, которые обусловили формирование системы отгонно-пастбищного животноводства. Исследованы способы содержания домашних животных в изучаемом регионе. Подвергнут анализу вопрос 0 роли животноводческой продукции в жизнеобеспечении казахов Чуйской степи.

Ключевые слова: казахское население, отгонно-пастбищное животноводство, мясомолочная пища, Чуйская степь, Республика Алтай.

устье р. Чаган-Бургазы и некоторая часть течения р. Чуи, выше с. Кош-Агач, были заняты исключительно казахами [11, с. 42]. В связи с тем, что местом кочевания этой этнической группы стала Чуйская степь и прилегающие к ней горные массивы, их стали именовать - чуйские казахи. По данным С.П. Швецова к началу XX в. в «Чуйском районе» было зарегистрировано «129 хозяйств» казахов, которые состояли из 279 мужчин и 280 женщин, всего 559 человек [33, с. 45].

Если статистические данные С.П. Швецова сравнить с современностью, то они показывают, что численность изучаемого казахского населения значительно выросла. Например, по последней Всероссийской переписи населения в 2010 г. в Кош-Агачском районе уже проживало 9747 казахов, по сравнении с началом XX в. их число (559 человек) увеличилось в 17 раз. В целом это 53,37\% населения Кош-Агачского района [34, с. 45; 26, с. 29]. В сегодняшние дни чуйские казахи сохранили свой язык и традиционные элементы культуры [28, с. 98-100; 13].

В науке мало работ исследующих роль животноводства в системе жизнеобеспечения чуйских казахов в пост советский период. Часто данная тема присутствует фрагментарно в публикациях по истории, культуре и хозяйственной деятельности населения Республики Алтай [6. с. $14 ; 11$, с. $183-184 ; 2$, с. $11-17$ и т.д.]. 
В 1990-х - 2010-х гг. основным традиционным занятием населения Кош-Агачского района как коренных жителей алтайцев-теленгитов, так и чуйских казахов остаётся животноводство. Например, если на территории района на начало 1991 г. насчитывалось 62100 условных (усл.) голов (гол.) скота (коэффициент перевода в усл. гол. крупного скота: лошади - 1; коровы и быки производители - 1; овцы и козы - 0,1 [9]), тогда как к началу 2014 г. насчитывается - 55671 усл. гол. Если в 1991 г. на 1 жителя Кош-Агачского района приходилось - 3,5 усл. гол., то на 2014 г. приходилось - 3,0 усл. гол. А в 2017 г. в Кош-Агачском районе на 1 жителя приходилось - 3,6 усл. гол., что составило в количественном отношение более - 72317 усл. гол. скота, из них в СПК (сельскохозяйственный производственный кооператив) - 10920 усл. гол. (16\% от общего числа), КФХ (крестьянско-фермерские хозяйства) приходилось - 19792 усл. гол. (29\% от общего числа), в ЛПХ (личные подсобные хозяйства) - 37536 усл. гол. (55\% от общего числа) [4; 5].

В связи с тем, что работа посвящена животноводству этнической группы казахов, основная масса которых проживают в Чуйской степи, поэтому кратко опишем природно-климатические условия этой местности. КошАгачский район - это одно из отдаленных административных образований Республики Алтай, который расположен на юго-востоке Алтая. Чуйская степи - это самая крупная межгорная впадина - котловина в юго-восточной части Кош-Агачского района. Длина Чуйской степи - 70 км., ширина - 10-40 км. Степь обрамлена с севера Курайским хребтом, с юга - Южно-Чуйским, с запада она ограничена Северо-Чуйским хребтом и с востока хребтом Чихачева. Также это самая высокая из горных котловин Алтая, что придает ее растительному и животному миру характерные высокогорные черты (Чуйская степь находится на высотах 1700-1800 м над уровнем моря, а окрестные хребты поднимаются свыше 4000 м) [6, с. 14; 32].

Климат Чуйской степи сухой и холодный, резко-континентальный. Зима малоснежная, холода длятся более 7 месяцев, повсеместно встречается вечная мерзлота. Среднегодовая температура (по данным Кош-Агачской метеостанции) $6,6^{\circ} \mathrm{C}$, возможно падение до $-60^{\circ} \mathrm{C}$ зимой. Летом температура может подниматься и до $+30^{\circ} \mathrm{C}$. Количество осадков совсем невелико - в среднем 100 мм. в год, наибольшее количество осадков выпадает летом, зимы малоснежные и, кроме этого, снег сдувается ветром [31].

Большие колебания высот рельефа Кош-Агачского района (от 1400 до 4200 м. над уровнем моря) создают ясно выраженную вертикальную зональность растительности, именно эта особенность распределения растительности выработала у живущих здесь скотоводов вертикальный отгонно-пастбищный способ выпас жи- вотных [6. с. 14]. Непосредственно в Чуйской степи местное население свои стада круглый год пасут на открытых пастбищах. Таковыми с начала лета до начало осени являются горные луга. А в холодное время года скот пасут в долинах Чуйской степи $[14 ; 15 ; 20]$.

Поскольку основным лимитирующим фактором в организации традиционного хозяйства населения Чуйской степи выступают природно-климатические условия, то практикуемое в исследуемой территории отгонное скотоводство является наиболее рациональным. Оно позволяет не истощать местные пастбищные ресурсы, удовлетворяя потребности скотоводства при минимальных затратах труда [2, с. 11].

Надо отметить, сложившаяся система содержания скота в изучаемом регионе не претерпела значительных изменений с глубокой древности. По мнению большинства исследователей-археологов на территории Горного Алтая в эпоху ранней бронзы в афанасьевском периоде уже осуществлялись сезонные перекочевки: в летнее время на высокогорные пастбища, а на зиму - в долины [8, с. 114-115].

В 2010-х гг. чуйские казахи, традиционно занимаясь отгонно-пастбищным животноводством, продолжают выращивать лошадей, крупный (коровы, яки) и мелкий (овцы, козы) рогатый скот и верблюдов. Например, у жителей с. Жана-Аул к началу лета 2019 г. (в селе на начало 2019 г. проживало - 1310 человек [27]) крупнорогатого скота (КРС) в ЛПХ было около 3000 голов (гол.), все хозяйства сельского поселения держали лошадей - 700 гол. и мелко-рогатого скота (МРС) - 24-25 тыс. гол., в СПК разводили яков - 250 гол. [15].

Население Чуйской степи свой домашний скот на летние пастбища обычно перегоняют в конце мая или начале лета, когда растают льды на путях перекочевок. Например, в 2019 г. животных в высокогорья подымали 1 июня. Во время наших полевых исследований информанты рассказали, что летние пастбища (Әжайляу) скотоводов из населенных пунктов Кош-Агач, Тобелер и Жана-Аул находятся в западных отрогах и склонах хребта Чихачева в приграничной зоне с Республикой Тывой [20; 21; 24]. Так, информант, специалист по сельскому хозяйству с. Жана-Аул А.Б. Бакытов, рассказал, что летние стоянки жителей этого села распложены в местностях Юстыт, Адрыгы тал, Кара-Мандай, Бугуты и КиндыктыКоль [15]. Житель с. Тобелер О.А. Имамадиев летом свой скот пасет в местности Бугузун в урочище Текелю «около границы с Тувой (Республика Тыва)» [17]. Там же в местности Бугузун находится летняя стоянка фермера из с. Тобелер Ж.Б. Каранова [20].

На летниках домашних животных КРС, MPC и лошадей пасут отдельно друг от друга. Чаще всего профессии 
животновода (чабана, пастуха и табунщика) передаются по семейно-династической линии или через институт наставничества [16; 20]. Например, О.А. Имамадиев в советский период 15 лет пас колхозных яков. В 2019 г. он частник, вместе с сыном выращивает свой скот [17].

В селах на лето оставляют только дойных коров, обычно 1-3 головы на хозяйство, это если молоко доят для собственного употребления. Больше 5-8 дойных животных оставляют те, кто изготавливают молочные продукты (кислый сыр - курт, сливочное масло, сливки) для реализации за деньги. Оставленные в селах дойные коровы ночуют в хозяйственных постройках, возведенных на участке прилегающих к хозяйскому дому. В дневное время эти животные пасутся в окрестностях села. Доят их два раза утром и вечером.

В 2000-х гг. источником дохода стал кумыс, который также реализуют за деньги. Поэтому некоторые хозяйства не отгоняют на летники и кобыл, у которых доят молоко для получения этого кисломолочного продукта. Например, фермер ж.Б. Каранов, житель с. Тобелер рассказал, что у него примерно в 10 км. южнее от села есть ферма - кумысная - это бывший зимник, где он держит кобыл для дойки [20].

В 2000-х гг. скот многих частников выпасают за плату. Так в 2019 г. выпас одной головы животного за один месяц стоил: МРС - 30 руб., КРС - 300 руб., за лошадь - 300 руб., за пастьбу дойных коров, которые находятся в селах, платили - 250 руб. [30].

В первых числах августа население Чуйской степи начинает заготовку сена для зимнего содержания скота. Во многом сохранность скота в холодное время года зависит от количества и качества запасенного сена. В 2010х гг. сено косят тракторными косилками, мотоблоками, некоторые ручной косой. Но последний способ практикуют все реже. После скашивания сено сохнет, затем ее собирают и на автомобилях или в тракторных прицепах отвозят в места зимовки скота. Многие хозяйства сено дополнительно ещё закупают, часто с Алтайского края $[14 ; 20]$.

С летних пастбищ скот начинают спускать примерно в конце августа, а некоторые частники раньше, так как надо успеть сдать часть животных приемщикам, которые в это время уже начинают закупку в живом весе. На полученные деньги за продажу скота люди готовят школьников к учебе, покупают им одежду, учебные принадлежности, отправляют студентов на учебу [14; 20; 21$]$.

Спустив скот с высокогорных летних пастбищ, животных распределяют по местам зимовья. Большинство зимних пастбищ (кыстау) чуйских казахов распложены в самой Чуйской степи, так как в холодный сезон она край- не неравномерно и слабо заснежена [15; 32].

Как правило, многие ЛПХ в основном своих овец и коз содержат в зимних стоянках у частников-скотоводств за определенную плату. Информант рассказал, что многие казахи с. Кош-Агач имеют от 40 до 100 овец и коз. Эти животные с наступлением холодного периода находятся на зимниках у частников. Обычно в зимних стоянках мелко-рогатый скот находится до марта. Затем хозяева своих животных перегоняют к себе домой, где их содержат в надворных постройках. Здесь у самок овец и коз проходит окот [24]. Но если зима суровая, холодная и многоснежная, то частники-скотоводы МРС отдают хозяевам в январе, феврале месяцах. В зимних стоянках КРС и лошадей держат обычно те хозяйства, которые специализируются на выведении этих животных [14; 16; 20].

Зимние стоянки казахов из селений Кош-Агач, Тобелер и Жана-Аул в основном находятся в 5-40 км. к югу или юго-востоку от этих населенных пунктов [14; 20; 22]. Например, житель с. Тобелер Ж.С. Каранов, в холодное время года свой скот пасет в 25 км. южнее от населенного пункта [21]. А самые дальние зимники животноводов с. Жана-Аул расположены почти на юго-восточной оконечности Чуйской степи в местности Уландрык [15; 2, с. 14]. Зимние стоянки, как правило, расположены: «на наименее заснеженных и наиболее комфортных для содержания скота безветренных (подветренных) и наименее затененных местах, преимущественно у подножья склонов южных румбов экспозиции. Более интенсивное таяние и ветроперенос снежного покрова с этих склонов облегчают размещение и выпас на них овец и коз» [2, с. 15-16]. Сами зимние стоянки имеют специализированные крытые постройки для скота, куда его загоняют на ночь. Эти помещения существенно облегчают перезимовку животных во время холодов. Часто, это прямоугольные помещения, построенные из дерева, имеющие двухскатные крыши [16; 20; 24].

Многие хозяйства чуйских казахов особенно ЛПХ свой КРС весь холодный сезон содержат в населенных пунктах. В этом случае скот ночует в хозяйственных постройках, возведенных на участке прилегающих к хозяйскому дому. В дневное время эти животные пасутся в окрестностях села. Например, в нашей беседе информант О.А. Имамадиев, проживающий в с. Тобелер, рассказал, что он свой КРС - 49 голов (20 коров - взрослых голов, 29 яков) в холодное время содержит во дворе своего дома в специальных хозяйственных постройках [17].

Зимой КРС и МРС пасутся недалеко от стоянки (или от населенного пункта, если животные зимуют во дворе хозяина) в окрестных лугах и долинах. На ночь животные приходят на свои места постоянных ночевок в пригоны, сараи и стойла. Зимой скотоводы Чуйской степи животных подкармливают один раз в день. Вечером они 
дают сено, некоторые хозяева и комбикорма. Лошади обычно находятся на свободном выпасе - тебенёвке, за ними лишь присматривают в местах их пастьбы. Коней подкармливают, если зима неблагоприятна, например, когда выпало много снега, из-за чего животным трудно тебеневаться, и когда лошади слабеют, им начинают давать сено [16; 20; 24].

Выпас скота на многих зимних пастбищах Чуйсой степи осуществляется с конца августа - начала сентября по конец мая - начало июня, то есть фактически это осенне-зимне-весенние пастбища. Скот на зимних стоянках содержится около 9 месяцев в году, на летних - около 3 месяцев [14; 20; 24; 2, с. 16]. Так, на начало 2014 г. в КошАгачском районе имелось - 652 животноводческих стоянок, в том числе зимних, весенних, осенних - 369 и летних - 283 стоянок [4].

В силу своей хозяйственной деятельности, основу питания чуйских казахов традиционно составляют мясные и молочные продукты. Эта богатая животным белком и жиром пища помогает поддерживать жизнедеятельность организма человека в холодном и дискомфортном регионе, как Кош-Агачский район (район в 1992 г. был приравнен к региону крайнего севера) [29, с. 36; 31].

В 2010-х гг., как и в предшествующие периоды, в питании чуйских казахов мясо остается главным продуктом круглый год [13; 15; 25]. Население Чуйской степи основную заготовку мяса производят поздней осенью с наступлением стабильных холодов. В это время животные наиболее упитаны. После забоя мясо домашних животных замораживается и в таком состоянии хранится. Весь запас замороженного на зиму мяса казахи называют - согум. Величина согума зависит от материального достатка и от количества членов семьи. Так, если семья большая, где есть три поколения, например, пожилая супружеская пара, их дети со своей семьей, забивают дватри КРС и до десяти баранов. Молодая семья с одним или двумя детьми на согум заготавливают одного КРС и двух-трех баранов [12; 13].

В связи с тем, что у казахов мясо - эта основная и любимая пища, поэтому забитое животное используется полностью, обязательно употребляют и внутренности. Например, во время осеннего забоя - согум из внутренностей животного, которые покрыты жиром, готовят различные блюда. Так, в сегодняшние дни у казахов одним из любимых блюд, как и в предшествующие периоды, остаются - казы и карта, которые готовят из внутренностей лошади $[21 ; 23 ; 24]$. Из толстой кишки КРС готовят блюдо - кыймай. Для приготовления этого кушанья толстую кишку чистят, затем ее начиняют мясом, заправляют, луком и перцем, перед употреблением кыймай варят. Из внутренностей овцы готовят - жоргом. Для приготовления жоргома внутренности тщательно промывают в воде. Затем желудок и внутреннее сало разрезают на узкие полоски и сплетают с тонкими кишками в виде косички [13; 18]. Данное блюдо едят в вареном виде. Аналогичное кушанье есть в кухне других тюркских народов, например у алтайцев - дьоргом [7, с. 218-220].

В 2010-х гг. у казахов Чуйской степи мясные кушанья традиционно остаются главными угощениями на всех торжествах. По тому, как угощают гостей во время трапезы, можно определить статус присутствующих, так как к каждому преподносится та часть туши приготовленного животного, которая соответствует его возрасту и положению.

По обычаю казахов для уважаемых гостей чаще всего забивают баранов. После того как баранина сварится, её подают на стол. По гостевому этикету казахов, угощение начинают с мужчин старшего поколения или имеющего высокий социальный статус в обществе, им преподносят - бас табак - это главный и значимый поднос с мясом. В поднос для бас табак кладут овечью голову - бас, мясистую бедренную часть - жамбас, предплечье - каре жилик, позвоночник - арка, поясничную часть позвоночника - бельдеме, ребра - кабарга, крестцовую кость - жая. Женщинам преподносят голень - асыкты жилик, поясничную часть позвоночника - бельдеме и другие доли позвоночника (арка). Молодым мужчинам и юношам преподносят поднос с лопаткой - жаурын, ребрами (кабарга), предплечьем (каре жилик), крестцовую кость (жая). Если за столом хозяина, находится его зять - кую бала, ему как главное угощение преподносят грудинку тос и другие части мяса $[13 ; 24 ; 25]$.

В обычные дни мясо готовят по-разному: варят, жарят и тушат. Часто хозяйки варят мясной суп с лапшой - кеспе коже или мясной суп с перловой крупой - коп коже. В сегодняшние дни одним из любимых блюд казахов, как и в предшествующие периоды, остается - бешбармак. В этом кушанье мясо подают с кусками тонко раскатанного теста, сваренного в бульоне - сорnа, с подливом, состоящего из перца, соли и лука. Из говядины, баранины и конины готовят куырдак - жаркое из фарша или шинкованного мяса с картошкой или макаронами [13; 19; 23].

В 2000-х гг. как и в предшествующие периоды, важным компонентом питания чуйских казахов остаются молочные продукты. Из коровьего молока обычно готовят сметану и сливки - каймак, сливочное масло - май, творог - ыримшик, кислый сыр - курт, приправу - сузбе. Из кобыльего молока традиционно готовят кисломолочный напиток - кумыс, Также в сегодняшние дни в Кош-Агачском районе редко, но продолжают доить верблюдиц. Из верблюжьего молока изготавливают кисломолочный напиток - шубат [13; 18; 20].

В 2000-х гг. для приготовления масла - май молоко 
пропускают через сепаратор. Из полученных сливок каймак путем взбивания изготавливают сливочное масло. В 2010-х гг. все реже, но в некоторых семьях употребляют топленое масло - сары май, которое, как и ранее, продолжают хранить в овечьем желудке - карын [18; 19; 23].

Чуйские казахи готовят два вида ыримшика: белый ак и красный - кызыл. Ак ыримшик получают из свежего молока, которую наливают в емкость и ставят на огнь. Когда молоко нагревается, в неё добавляют кефир. Нагретое молоко сворачивается, образуя творожную массу. Эту массу процеживают, сливая сыворотку. Казыл ыримшик готовят, как и ак ыримшик, но его варят долго. При долгом кипении твороженная масса приобретает желто-красноватый цвет, поэтому его называют красный - кызыл ыримшик. Затем полученную массу сцеживают и дают подсохнуть $[13 ; 18 ; 19]$.

Чуйские казахи кислый сыр - курт изготавливают из айрана. Кисломолочный продукт - айран готовят из молока коровы. Молоко сливают в емкость, где оно заквашивается и превращается в айран. Собранный айран процеживают, получают творожную массу - ыркыт. Затем ыркыту придают форму, сушат и получают кислый сыр-курт $[13 ; 18]$.

Также из айрана готовят - сузбе, которая является добавкой во многие мясные блюда: супы, бульон - copny, подливы и т.д. Для приготовления сузбе айран наливают в емкость и ставят на медленный огонь. Когда айран нагревается, находящаяся в ней сыворотка начинает выпариваться и образуется сквашенная масса. Эту массу сцеживают, отделяя остатки сыворотки. Затем полученный бело-молочный продукт - сузбе солят по вкусу и замораживают [13; 18; 19$]$.

Из свежего кобыльего молока казахи готовят - кумыс. Для приготовления кумыса надоенное молоко процеживают через марлю, затем сливают в специальную емкость, добавляют в нее закваску и взбивают мутовкой, оставляют на ночь, и к утру напиток уже готов $[13 ; 18 ; 19]$.

В 2000-х гг. население Чуйской степи традиционно существенный денежный доход получают от реализации животноводческой продукции своего хозяйства. В работе уже отмечалось, что чуйские казахи на лето в населенных пунктах оставляют дойных коров, а кобыл - в кумысных для получения молочных продуктов под реализацию. Так, в 2019 г. молочную продукцию продавали по следующим ценам: 1 кг. кислого сыра - курт - 400 руб., 1 кг. сливочного масло - 600 руб., кумыс - 150 руб. за 1,5 лит. Эти продукты реализуются как через торговые точки, которые расположены в райцентре с. Кош-Агач, так и разносной торговлей с рук. В последнем случае покупателями являются односельчане [13; 18]. Также в работе уже отмечалось, что некоторые хозяйства скот в живом весе сдают в августе месяце для подготовки детей к учебе. Но основную массу скота население Чуйской степи сдают в сентябре-октябре месяцах, так как животные в это время особенно упитаны. Скупку скота осуществляют как местные коммерсанты, так и приезжие с других регионов. Например, в 2011 г. по Кош-Агачскому району было произведено мяса (скот на убой) - 7741,6 тонн (т.), молока - 5335,2 т., шерсти - 321,8 т., пуха - 499,1 центнеров [3]. Но в 2010-х гг. у скотоводческих хозяйств изучаемого региона остро стоит проблема реализации животноводческой продукции. Назовем основные факторы, повлиявшие на эту проблему: отдаленность региона, высокая обеспеченность местного населения скотом, неразвитость предприятий пищевой промышленности, а так же системы заготовок и транспортировки. В связи с чем часто местное население вынужденно продавать продукцию скотоводства за бесценок, например, в беседе информанты рассказали, что в 2018 г. живой вес КРС стоил 80 руб. за 1 кг. из них 13\% скидка: «Бычки и телки уходит по цене 15-20 тыс. руб. за голову, продаем задарма. За животными ухаживаешь не один год, а они за такие деньги сдаются скупщикам» [14]. Во время сбора полевого материал в 2019 г. в Кощ-Агачском районе информанты отметили, что в последние годы у населения перестали покупать овечью шерсть $[13 ; 14 ; 20]$. Но стабильно закупается козий пух и в основном гражданами Монголии. Так в 2018 г. они принимали пух по цене - 650-700 руб. за 1 кг. [13].

Для казахов Чуйской степи не характерно домашнее птицеводство. К началу 2000-х гг. все их потребности в мясе домашней птицы и куриных яйцах в первую очередь удовлетворялись через сетевые магазины. Но с 2010-х гг. некоторые хозяйства начали разводить домашних птиц, в основном кур [10, с. 62.]. Например, житель с. Кош-Агач А.С. Мусатаев рассказал, что он разводит породистых кур и индюков, первых у него 70, вторых 15 голов. Информант из продукции своего хозяйства реализует яйца, продавая 10 штук за - 80 руб., мясо индюков - 450 руб. за 1 кг. (цены на конец мая 2019 г.). Также он местному населению для разведения продает цыплят кур и индюков. В беседе А.С. Мусатаев рассказал, что мясо птицы и яйца у него берут хорошо, так как вся его продукция выращена на естественных кормах - «не магазинное», а яйца даже дешевле (например, весной 2019 г. на рынке г. Горно-Алтайска продавцы 10 яиц с местных личных подсобных хозяйств продавали за 100 руб.) [22].

Таким образом, в 1990-2010-х гг. животноводство играет значительную роль в жизнеобеспечение чуйских казахов. Исторически основным лимитирующим фактором в организации хозяйственной деятельности населения изучаемого региона выступают природноклиматические условия. В связи с чем отгонно-пастбищное содержание домашних животных является наиболее 
приемлемой в Чуйской степи.

В 2010-х гг. мясные и молочные продукты, как и в предшествующие периоды, продолжают составлять основу питания казахов Чуйской степи. Вследствие этого в их пищевом рационе большое место занимают национальные блюда. Богатая животным белком и жиром традиционная пища чуйских казахов существенно поддерживает жизнедеятельность в суровых условиях КошАгачского района.

В 2010-х гг. для многих хозяйств чуйских казахов животноводческая деятельность остается одним из основных источников денежных доходов. Например, значительная часть денежных средств получают от реализации скота в живом весе. Некоторые хозяйства специализируются на продаже молочных продуктов.

Надо отметить, процессы глобализации способствовали актуализации и адаптации сложившихся способов хозяйственной деятельности к современности, например, если в предшествующие периоды для изучаемого этноса не характерно было домашнее птицеводство, то в 2010-х гг. уже появились хозяйства, разводящие домашних птиц, продукция которых реализуется населению региона.

\section{ЛИТЕРАТУРА}

1. Алтайцы: Этническая история. Традиционная культура. Современное развитие/ редколл. Н.В. Екеев (отв. ред.), Н.М. Екеева, Э.В. Енчинов; НИИ алтаистики им. С.С. Суразакова. Горно-Алтайск, 2014. 464 с. + 3 цвет. вкл.

2. Байлагазов Л.В. Использование пастбищ в свете создания национального парка на хребте Сайлюгем (Республика Алтай) // Степной Бюллетень. 2011. № 31. С. 11-17.

3. Доклад главы по итогам социально-экономического развития M0 «Кош-Агачский район» за 2011 год [Электронный ресурc]. URL: https://docplayer. ru/31168993-Doklad-glavy-po-itogam-socialno-ekonomicheskogo-razvitiya-mo-kosh-agachskiy-rayon-za-2011-god.html (дата 0бращения: 20.01.2020).

4. Доклад начальника отдела сельского хозяйства M0 «Кош-Агачский район» Акболата Джунисова [Электронный ресурc] URL: https://gornoaltaysk. bezformata.com/listnews/hozyajstva-mo-kosh-agachskij-rajon/21377844/ (дата обращения: 25.11.2019).

5. Доклад. «0 ходе кормозаготовительной компании в Кош-Агачском районе на 10.08.2017года» [Электронный ресуpc]. URL: http://mcx-altai.ru/ attachments/article/899/220817-2_doklad_kosh-agach.docx (дата обращения: 20.01.2020).

6. Дьяконова В.П. Алтайцы (материалы по этнографии теленгитов Горного Алтая). Горно-Алтайск: Юч-Сумер - Белуха, 2001. 224 с.

7. Енчинов Э.В. Дьоргом - престижное потребление в алтайской традиции питания // Полевые исследования на Алтае, в Прииртышье и Верхнем Приобье (археология, этнография, устная история). 2017 год. Вып. 13: Материалы XIII международной научно-практической конференции. Горно-Алтайск: БИЦ ГАГУ, 2018. С. 216-222.

8. История Республики Алтай. Т. ІІ. Горный Алтай в составе Российского государства (1756-1916 гг.) / НиИ алтаистики им. С.С. Суразакова; редколл. Н.В. Екеев (отв. ред.), Н.М. Екеева, З.С. Казагачева, Н.А. Майдурова. Горно-Алтайск: ОАО «Горно-Алтайская типография», 2010. 472 с.

9. Коэффициенты перевода в животноводстве [Электронный ресурс]. URL: http://logus-elho.ru/no/108 (дата обращения: 25.01.2020).

10. Ларина Е.И., Наумова 0.Б. Кош-Агачские казахи-мигранты // Вестник Евразии. № 2. 2008. С. 45-65.

11. Макошев А.П. Вопросы территориальной организации горно-животноводческого хозяйства Алтая: монография. - Горно-Алтайск: РИО ГАГУ, 2010.264 с.

12. НА НИИА. МНЭ (Научный архив Научно-исследовательского института алтаистики им. С. С. Суразакова. Материалы научной экспедиции). Д. № 139. [Абитова К. А. 1982 г. р.].

13. НА НИИА. МНЭ. Д. № 139. [Аккожанова Е. С. 1960 г. р.].

14. НА НИИА. МНЭ. Д. № 139. [Ауганбаев А. Д. 1963 г. р.].

15. НА НИИА. МНЭ. Д. № 139. [Бакытов А. Б. 1987 г. р.].

16. НА НИИА. МНэ. Д. № 139. [Едельбаев Е.Б. 1974 г. р.].

17. НА НИИА. МНЭ. Д. № 139. [Имамадиев 0.А. 1955 г. р.].

18. НА НИИА. МНЭ. Д. № 139. [Имамадиева К.С. 1958 г. р.].

19. НА НИИА. МНЭ. Д. № 139. [Кабдулова Ж. Р. 1971 г. р.]

20. НА НИИА. МНЭ. Д. № 139. [Каранов Ж. Б. 1970 г. р.].

21. НА НИИА. МНЭ. Д. № 139. [Каранов Ж. С. 1972 г. р.].

22. НА НИИА. МНЭ. Д. № 139. [Мусатаев А.С. 1973 г. р.].

23. НА НИИА. МНЭ. Д. № 139. [Нурсалиева Ж.К. 1971 г. р.].

24. НА НИИА. МНЭ. Д. № 139. [Оспанов Д. К. 1974 г. р.].

25. НА НИИА. МНЭ. Д. № 139. [Оспанов К.М. 1937 г. р.].

26. Национальный состав и владение языками, гражданство: Стат. Сборник Алтайстат - г. Горно-Алтайск, 2013. 419 с.

27. Общая информация. Казахское сельское поселение Кош-Агачского района: [сайт]. [2020]. URL: http://zhana-aulsp.ru/selskoe-poselenie/obshhayainformatsiya/ (дата обращения: 26.01.2020).

28. Октябрьская И.В. Казахи Алтая. История и современность // Этнографическое обозрение. 1997. № 6. С. 92-102. 
29. Селин В.С. Вышинская Ю.В. Нормативное регулирование и комплексное природохозяйственное районирование Севера и Арктики //Труды Карельского научного центра РАН. № 5. 2013. С. 31-39.

30. Собрания граждан с. Жана-Аул. Протокол. №3. От 10 апреля 2019г. [Электронный ресурс] // Казахское сельское поселение Кош-Агачского района Республики Алтай: [сайт]. [2019]. URL: http://zhana-aulsp.ru/2019/04/2527/ (дата обращения: 23.12.2019).

31. Схема территориального планирования M0 «Кош-Агачский район» Республики Алтай [Электронный ресурс]. URL: http://lib.convdocs.org/docs/ index-10867.html?page=2 (дата обращения: 12.02.2020).

32. Чуйская степь [Электронный ресурc]. URL: https://ru.wikipedia.org/wiki/ (дата обращения: 12.02.2020).

33. Швецов С.П. Репринтное воспроизведение издания «Горный Алтай и его население. Кочевники Бийского уезда». Барнаул, 1900. Горно-Алтайск: Ак Чечек, 2008. $571 \mathrm{C}$.

(c) Торушев Эркем Геннадьевич (erktor@mail.ru).

Журнал «Современная наука: актуальные проблемы теории и практики»

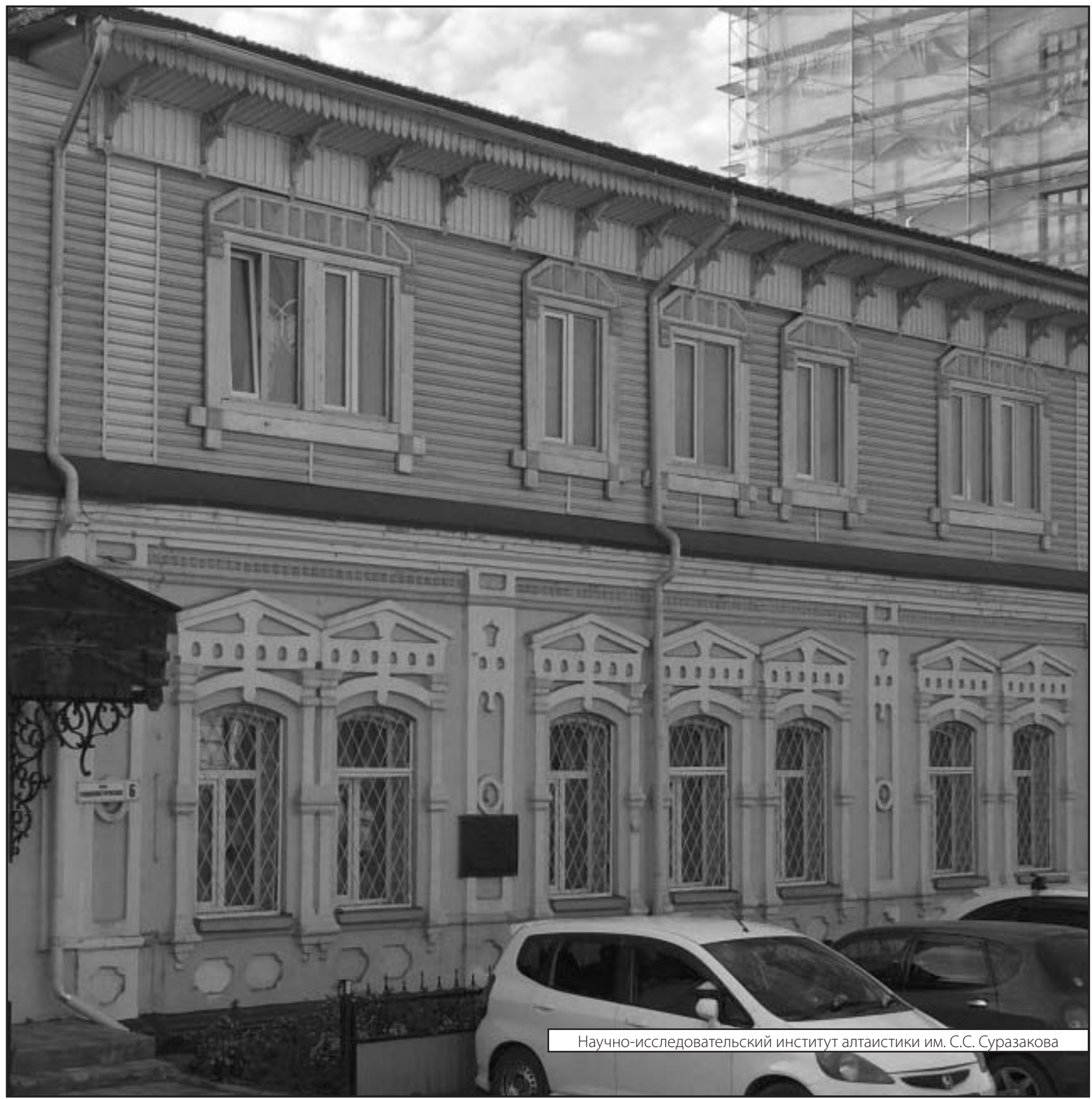

